\title{
OPEN Rice husk ash addition to acid red soil improves the soil property and cotton seedling growth
}

\begin{abstract}
Mengyao Yin, Xuan Li, Qian Liu \& Feiyu Tang
Red soil is characterized by poor physico-chemical properties and low nutrient availability. The present study aimed to examine rich husk ash (RHA) incorporation into red soil at various rates effects on its properties and the growth of cotton seedlings under a plug-seeding in tray experiment. Bulk density was decreased, and water holding capacity and total porosity were increased in red soil with increasing application rate of RHA. The addition of RHA counteracts the acidity of red soil and improves the nutrient availability to plants. The RHA incorporated soils favored the growth of cotton seedlings with improved shoot morphological traits and root architectures. The application rate at a volume ratio of 1:1 of RHA to red soil was found to be optimal for growing cotton seedlings in the present study. The mixture of RHA and red soil at a 1:1 volume ratio plus $2 \mathrm{~g} \mathrm{~L}^{-1}$ super absorbent polymers exhibited a high nursing seedling efficiency comparable to a commercial growing media under the condition of foliar application of mepiquat chloride at the one-true-leaf stage. RHA can be a promising substitute for peat as growing media for nursing cotton seedlings.
\end{abstract}

There are around 10.8 Mha of red soil in Jiangxi province China representing 64\% of the total land area ${ }^{1}$. Red soil is derived from Quatenary red clay and categorized as Ferralic Cambisol ${ }^{2,3}$, which is characterized by poor chemical and physical characteristics such as low $\mathrm{pH}$ value and cation exchange capacity (CEC), low fertility (scarcity of potassium $\mathrm{K}$, phosphorus $\mathrm{P}$ and calcium $\mathrm{Ca}$, etc.), and high content of activated aluminum ion $\left(\mathrm{Al}^{3+}\right)$, bad aeration and thin organic soil layer ${ }^{1,3}$. Cotton is grown widely in the hill red soil region of the middle-north section of Jiangxi province as a staple industrial $\mathrm{crop}^{4}$. It is difficult for the type of soil to produce comparatively high cotton lint yield due to its intrinsic drawback ${ }^{5}$. Thus, it is imperative to ameliorate the physical, chemical and biological properties of red soil for further enhancement of cotton productivity.

Jiangxi province is known as the largest third paddy rice production region in China with an annual production area of 3.30 Mha and a total yield above 20 million tons over the last decade ${ }^{6}$. Rice husk is a main byproduct during the milling process of paddy rice accounting for about $20-22 \%$ of rice kernel by weight ${ }^{7,8}$. The disposition of rich husk remains a main issue for the rice mill industry. Inappropriate disposition methods such as onsite burning, open dumping or land-filling may bring serious threats to environmental sustainability ${ }^{8}$. Rice husk can be used as fuel to generate electricity on a commercial scale. The residue ash is called rice husk ash (RHA) after the combustion of rice husk. Depending on whether the combustion is complete or incomplete, rice husk ash is classified as white (WRHA) and black (BRHA) ones, or RHA1 and RHA2 with RHA1 being longer exposed to furnace than RHA $2^{10}$. At present, RHA is mainly utilized as a pozzolanic material, adsorbent and source of silica, etc. ${ }^{11}$, but its usage in the agriculture industry is still scarce.

RHA is rich in chemical elements like $\mathrm{K}, \mathrm{P}, \mathrm{Ca}$, Magnesium $(\mathrm{Mg})$ and silicon $(\mathrm{Si})$, and moderately alkaline and has considerable neutralizing power which confers it an application of fertilizer ${ }^{10,12}$. RHA contains threelayered structures: internal, external and interface with interstitial and honeycombed pores ${ }^{11}$. Scanning electron micrograph (SEM) photograph of RHA indicated its high porosity leading to a huge specific surface area (SSA) and superior absorptive ability ${ }^{13}$. Similarly, Singh et al. (2019) also observed the presence of various macro- and micro-pores on the surface of RHA $^{14}$. Thus, RHA can be employed to remediate the heavy metal contaminated soil. The incorporation of RHA to $\mathrm{Pb}$ contaminated soil mitigated $\mathrm{Pb}$ damage to $R$. communis, and enhanced the uptake of nutrients and the activities of antioxidant enzymes ${ }^{15}$. RHA significantly reduced inorganic arsenic (As) accumulation in rice grains ${ }^{16}$. In addition, RHA has been widely used as an absorbent for the removal of lead $\left(\mathrm{Pb}(\mathrm{II})\right.$ and mercury $(\mathrm{Hg}(\mathrm{II}))$ from an aqueous solution ${ }^{11}$. In comparison to its role as a soil amendment, the utilization of RHA as growing media has drawn much less attention ${ }^{17}$. Virtually, RHA is a potential substitute for peat in growing media due to its chemical and physical attributes similar to biochar which is deemed as a 
promising replacement for peat ${ }^{10,17}$. Biochar and peat shared the common physico-chemical properties such as high water and air holding ability and CEC and lightweight ${ }^{18-20}$, but peat is a non-renewable resource and its regeneration takes a very long time ${ }^{21}$. Couples of types of biochars usage as a growing media were investigated and characterized by improved soil properties and seedlings growth ${ }^{21,22}$. Nevertheless, RHA does not be examined for its potential application value as a growing media.

Jiangxi province is located in subtropical monsoon climate region with excessive precipitation and frequent hit of cold wave from the north at the cotton seedling stage. Direct seeding is difficult to ensure full standing of cotton seedlings. Thus, seedling transplantation technology is widely adopted by cotton growers in that production area. Commercial growing media is usually not cheap specifically the transport cost is very high, and in turn increases the financial pressure on farmers. The manufacture of rice husk biochar (RHB) commonly takes a longer time and consumes considerable electricity, and therefore is less profitable economically. By contrast, RHA is abundantly available at a throw-away price as a byproduct of rice milling and steam and electricity generations. Certain properties of RHA above-mentioned may offset the inherent shortage of acid red soil. In the present study, we hypothesized that RHA incorporation into acid red soil can ameliorate the physico-chemical properties of soil and improve the growth parameters of cotton seedlings. The objectives of this study were to (i) examine the effect of RHA application as a growing media substrate on the physical and chemical characteristics of red soil; (ii) to determine the influence of RHA application on the physiological and growth parameters of cotton seedlings; (iii) verify whether there are significant differences or not in nursing seedlings between RHA media and a widely used commercial growing media. If RHA is utilized as a growing media, it can not only avoid the damage to the environment but also bring an economic benefit.

\section{Materials and methods}

Rice husk ash, red soil and treatment details. RHA was taken from a local rice mill in which rice husk was burnt to produce steam for the processing of paddy rice. The RHA shares multiple common physical and chemical characteristics with rice husk biochar (RHB) which is the product of the slow pyrolysis of rice husk under little or no oxygen condition ${ }^{10,15,16}$. Compared to RHA, RHB had greater carbon content, nitrogen content, neutralizing power, $\mathrm{pH}$ value, $\mathrm{CEC}$, and SSA, and much less silicon content, but no difference in macro-and micro nutrients including $\mathrm{K}, \mathrm{P}, \mathrm{Ca}, \mathrm{Mg}$, Manganese $(\mathrm{Mn})$, Iron $(\mathrm{Fe})^{10,12}$. In addition, the manufacture of RHB typically consumes substantial energy and takes longer time relative to RHA as a by-product of the mill industry. The RHA was water-saturated and black-colored when applied to soil. Red soil was taken from an uncultivated soil layer at a depth of $30 \mathrm{~cm}$ in the campus of Jiangxi Agricultural University, Nanchang China $\left(28^{\circ} 46^{\prime} \mathrm{N}, 115^{\circ}\right.$ $55^{\prime} \mathrm{E}$ ), which was classified as Ferralic $\mathrm{Cambisol}^{2,3}$. The usage of uncultivated soil aimed to minimize herbicide, pesticide and pathogen residuals influence on cotton seedlings. The soil was air-dried, and then ground finely to pass through a sieve of $2 \mathrm{~mm}$ mesh. RHA was added to the soil one week before seeding at volume ratios of 1:0, 1:1, 2:1, and 1:2 (soil: RHA), and then mixed thoroughly by hand. The mixtures of soil versus RHA at volume ratios of 1:0, 1:1, 2:1, and 1:2 were defined as T0 (pure soil, the control), T1, T2, T3, respectively in experiment 1.

A second experiment was conducted to assess the effects of an optimized synthetic growing media formula (red soil combined with RHA at a ratio of $1: 1 \mathrm{v} / \mathrm{v}, 2 \mathrm{~g} \mathrm{~L}^{-1}$ super absorbent polymers (SAP) (chemical name: potassium polyacrylamide, Renqiu Chemical Industry Co. Ltd, Renqiu city China) on cotton seedling growth. The formula was evidenced to perform best in previous preliminary tests. Experiment 2 included the following four treatments: T0 (pure soil), T5 (pure soil $+50 \mathrm{mg} \mathrm{L}^{-1}$ mepiquat chloride (MC) foliar painting at the one-true-leaf stage), T6 (red soil combined with RHA at a ratio of $1: 1 \mathrm{v} / \mathrm{v}+2 \mathrm{~g} \mathrm{~L}^{-1} \mathrm{SAP}+50 \mathrm{mg} \mathrm{L} \mathrm{MC}^{-1}$ foliar painting at the one-true-leaf stage), and T7 (commercial nutrient soil with a trademark name of HUANUO, Shenyang Haoyuan Environmental Service Co. Ltd, Shenyang city China, plus $50 \mathrm{mg} \mathrm{L}^{-1} \mathrm{MC}$ foliar painting at the one-true-leaf stage). The commercial nutrient soil contains peat, perlite, straw fibers, carbendazim, and rooting power, etc., as shown in the operation instruction.

Experimental design and growth conditions. Cotton seeds were planted in 72-cave plastic trays with $37 \mathrm{~cm}$ in length and $28 \mathrm{~cm}$ in width. The upper and bottom diameters of the cave were $3.5 \mathrm{~cm}$ and $1 \mathrm{~cm}$, respectively, and the total volume of each cave was $25 \mathrm{~mL}$. The two experiments were arranged in a randomized complete block design with four treatments, and each treatment was repeated triple. Each of the plastic trays represented a replication and seventy-two seeds in each. The growth conditions in the greenhouse were set to be as follows: temperature $28 / 25^{\circ} \mathrm{C}$ (day/night), photoperiod $16 / 8 \mathrm{~h}$ (light/dark), and light intensity $160 \mu \mathrm{mol} \mathrm{m}^{-2} \mathrm{~s}^{-1}$.

Measurements. Ten normal seedlings were randomly sampled from each of plastic trays for measurement of the physiological and growth parameters at the three-true-leaf stage (about 1 month after seeding later), and then separated into three parts: root, stem, and leaf. A portion of subsamples was oven-dried at $105^{\circ} \mathrm{C}$ for $30 \mathrm{~min}$ and then at $70^{\circ} \mathrm{C}$ to constant weight. The fresh and dry weights were recorded, respectively. Dry subsamples were ground into fine powders for the determination of hexose, sucrose, starch, total carbon, and total nitrogen. The growing media with various ratios of red soil to RHA was subjected to analysis of physico-chemical properties at the end of the experiment. Soil bulk density (BD) was determined by the cutting-ring method as described by Liu ${ }^{23}$. Total porosity and water holding capacity (WHC) were measured according to Chang et al. ${ }^{22}$. $\mathrm{pH}$ value was measured in a 1:2.5 soil to deionized water mixture ${ }^{12}$. Available phosphorus was determined by the Olsen-P method, and Available potassium was extracted by ammonium acetate solution and quantified by a flame photometer ${ }^{24}$. Organic matter was measured following the titanium trichloride-potassium dichromate method $^{24}$. Soil total nitrogen quantification was done by the Kjeldahl method. Nitrate nitrogen and ammoniacal nitrogen were determined according to the phenol-disulphonic acid and indophenol blue colorimetric methods, respectively ${ }^{24}$. Emergence rate was calculated as the percentage of survival seedlings to total seeds for each of 


\begin{tabular}{|l|l|c|l|c|l|}
\hline Treatment & $\mathbf{p H}$ value & Available $\mathbf{P}\left(\mathbf{m g ~ k g}^{-\mathbf{1}}\right)$ & Available $\mathbf{K}\left(\mathbf{m g ~ k g}^{-1}\right)$ & Organic matter $\left(\mathrm{g} \mathrm{kg}^{-\mathbf{1}}\right)$ & Total N $(\%)$ \\
\hline Red soil & $4.46 \pm 0.20 \mathrm{~b}$ & $5.85 \pm 0.64 \mathrm{~b}$ & $100.00 \pm 0.00 \mathrm{~b}$ & $6.85 \pm 0.35 \mathrm{~b}$ & $0.04 \pm 0.00 \mathrm{~b}$ \\
\hline RHA & $7.89 \pm 0.08 \mathrm{a}$ & $78.70 \pm 0.28 \mathrm{a}$ & $833.50 \pm 9.19 \mathrm{a}$ & $390.20 \pm 15.56 \mathrm{a}$ & $0.09 \pm 0.00 \mathrm{a}$ \\
\hline
\end{tabular}

Table 1. Chemical properties of rice husk ash (RHA) and red soil. Values followed by different letters within the same column are statistically different at $\mathrm{P} \leq 0.05$ level. Values are presented as means $\pm \mathrm{SD}$. The same as below.

\begin{tabular}{|l|l|l|l|}
\hline Growing media & Bulk density $\left(\mathrm{g} \mathrm{cm}^{-3}\right)$ & Water holding capacity (\%) & Total porosity (\%) \\
\hline T0 & $1.07 \pm 0.04 \mathrm{a}$ & $56.30 \pm 1.18 \mathrm{~d}$ & $51.43 \pm 1.88 \mathrm{c}$ \\
\hline T1 & $0.72 \pm 0.04 \mathrm{~b}$ & $93.77 \pm 2.25 \mathrm{~b}$ & $67.30 \pm 1.65 \mathrm{~b}$ \\
\hline T2 & $1.02 \pm 0.01 \mathrm{a}$ & $80.02 \pm 1.87 \mathrm{c}$ & $54.02 \pm 0.30 \mathrm{c}$ \\
\hline T3 & $0.44 \pm 0.05 \mathrm{c}$ & $132.13 \pm 10.66 \mathrm{a}$ & $79.96 \pm 1.19 \mathrm{a}$ \\
\hline
\end{tabular}

Table 2. Physical properties of the mixtures of rice husk ash and red soil with various. Proportions. T0, T1, $\mathrm{T} 2$, and T3 indicate the mixture of red soil to RHA at volume ratios of 1:0, 1:1, 2:1, and 1:2, respectively. The same as below.

treatments at the two cotyledons unfolding stage. Plant height was defined as the length from the base to the apex of plant. Root to shoot ratio was termed as the ratio of root dry weight to shoot dry weight. Stem diameter was measured at the middle of the hypocotyl using a vernier caliper scale. Seed index (SI) and G value were calculated in terms of the following functions ${ }^{25}$.

$$
\begin{gathered}
S I=\left(\frac{S D}{P H}+\frac{R D W}{S D W}\right) \times(R D W+S D W), \\
G \text { value }=\frac{(R D W+S D W)}{\text { growth period }},
\end{gathered}
$$

where SI represents seed index; SD: stem diameter; $P H$ : plant height; $R D W$ : root dry weight; $S D W$ : shoot dry weight; growth period denotes days during seeding to sampling.

Roots were rinsed free of soil with tap water, and scanned by a root scanner (Expression 12000XL, J331B, Japan). Root architecture parameters were recorded by WinRHIZO software (WinRHIZO Pro, Regent Instruments, QC, Canada) including total root length, root surface area, root volume, average root diameter, and the number of root tips. The exaction and determination of nonstructural carbohydrates (hexose, sucrose, and starch) were conducted following our previous protocols ${ }^{26,27}$. Total carbon in seedling organs was determined using Multi N/C 2100 analyzer with HT 1300 solid module (Analytik-Jena, Germany) and total nitrogen using the Kjeldahl method. Root vigor was measured using the 2,3,5-triphenyl tetrazolium chloride (TTC) method as described by $\mathrm{Chen}^{28}$.

Statistical analysis. All data were subjected to one-way Analysis of Variance (ANOVA) and means were separated by Duncan's Multiple Range Test at a probability of 0.05 level using the SPSS package (ver. 18.0). The figures were produced by Origin 8.5. All methods and collection of plant materials were performed in accordance with the relevant institutional, national, and international guidelines and legislation.

\section{Results}

Properties of red soil, RHA and their mixtures. The chemical properties of red soil and RHA were listed in Table 1. Soil $\mathrm{pH}$, available $\mathrm{P}$ and $\mathrm{K}$, organic matter, and total $\mathrm{N}$ were found higher for RHA as compared to the red soil. As expected, red soil is acidic and RHA is moderately alkaline. RHA incorporation to red soil ameliorated its physical properties (Table 2). Compared to T0 (pure red soil), T1 (1:1 of red soil to RHA) and T3 (1:2 of red soil to RHA) decreased bulk density and increased total porosity. WHC was increased as the rate of RHA application was enhanced. RHA application also improved the chemical characteristics of red soil (Table 3). Diverse ratios of the mixture of RHA and red soil had greater $\mathrm{pH}$ value, available $\mathrm{P}$ and $\mathrm{K}$, organic matter and total $\mathrm{N}$ relative to pure red soil (T0). The more the addition of RHA to red soil, the greater these chemical characteristics in the mixtures. Ammonium nitrogen and nitrate nitrogen in red soil were enhanced slightly by RHA application. Taken together, RHA addition to red soil improved both physical and chemical properties. Bulk density was decreased by $4.67 \%$ to $58.88 \%$ while total porosity, available $\mathrm{P}$, available $\mathrm{K}$ and organic matter were increased by 5.04 to $55.47 \%, 2.2$ to 9.6 folds, 1.2 to 3.1 folds and 2.4 to 7.6 folds, respectively.

Seedling growth parameters. Plant height, stem diameter, seedling index and G value were enhanced by RHA application treatments, among which T1 performed the best, but no difference was observed in the emer- 


\begin{tabular}{|c|c|c|c|c|c|c|c|}
\hline Treatment & pH & Available $\mathrm{P}\left(\mathrm{mg} \mathrm{kg}^{-1}\right)$ & Available $\mathrm{K}\left(\mathrm{mg} \mathrm{kg}^{-1}\right)$ & Organic matter $\left(\mathrm{g} \mathrm{kg}^{-1}\right)$ & Total N (\%) & $\begin{array}{l}\text { Ammonium nitrogen } \\
\left(\mathrm{mg} \mathrm{kg}^{-1}\right)\end{array}$ & $\begin{array}{l}\text { Nitrate nitrogen } \\
\left(\mathrm{mg} \mathrm{kg}^{-1}\right)\end{array}$ \\
\hline T0 & $4.64 \pm 0.20 \mathrm{~b}$ & $5.58 \pm 0.64 \mathrm{~d}$ & $100.00 \pm 0.00 \mathrm{~d}$ & $6.85 \pm 0.35 \mathrm{~d}$ & $0.05 \pm 0.00 \mathrm{~b}$ & $18.90 \pm 0.99 \mathrm{a}$ & $25.90 \pm 0.14 \mathrm{~b}$ \\
\hline $\mathrm{T} 1$ & $5.43 \pm 0.28 \mathrm{a}$ & $29.90 \pm 4.67 \mathrm{~b}$ & $310.50 \pm 9.19 \mathrm{~b}$ & $36.50 \pm 0.42 b$ & $0.07 \pm 0.00 \mathrm{a}$ & $22.80 \pm 0.57 \mathrm{a}$ & $30.45 \pm 1.34 \mathrm{ab}$ \\
\hline $\mathrm{T} 2$ & $5.34 \pm 0.06 \mathrm{a}$ & $17.90 \pm 1.27 \mathrm{c}$ & $221.00 \pm 26.87 \mathrm{c}$ & $23.10 \pm 5.52 \mathrm{c}$ & $0.07 \pm 0.01 \mathrm{ab}$ & $21.25 \pm 2.76 \mathrm{a}$ & $27.75 \pm 1.20 \mathrm{ab}$ \\
\hline T3 & $5.66 \pm 0.04 a$ & $59.10 \pm 5.80 \mathrm{a}$ & $406.00 \pm 0.00 \mathrm{a}$ & $58.95 \pm 5.73 a$ & $0.09 \pm 0.01 \mathrm{a}$ & $23.35 \pm 4.17 \mathrm{a}$ & $31.70 \pm 3.54 a$ \\
\hline
\end{tabular}

Table 3. Chemical properties of the mixture of rice husk ash and red soil with various proportions.

\begin{tabular}{|l|l|l|l|l|l|l|}
\hline Treatment & $\begin{array}{l}\text { Emergence rate } \\
(\%)\end{array}$ & Plant height $(\mathbf{c m})$ & $\begin{array}{l}\text { Stem diameter } \\
(\mathbf{m m})\end{array}$ & Root to shoot ratio & Seedling index & $\begin{array}{l}\text { G value } \\
\left(\mathbf{m g ~ d a y}^{-1}\right)\end{array}$ \\
\hline T0 & $0.94 \pm 0.03 \mathrm{a}$ & $16.42 \pm 1.29 \mathrm{c}$ & $1.90 \pm 0.09 \mathrm{~b}$ & $0.13 \pm 0.04 \mathrm{a}$ & $0.57 \pm 0.11 \mathrm{c}$ & $0.07 \pm 0.00 \mathrm{~d}$ \\
\hline T1 & $0.96 \pm 0.03 \mathrm{a}$ & $25.77 \pm 2.64 \mathrm{a}$ & $2.36 \pm 0.13 \mathrm{a}$ & $0.12 \pm 0.02 \mathrm{a}$ & $1.07 \pm 0.07 \mathrm{a}$ & $0.16 \pm 0.02 \mathrm{a}$ \\
\hline T2 & $0.95 \pm 0.02 \mathrm{a}$ & $19.96 \pm 0.94 \mathrm{~b}$ & $2.06 \pm 0.11 \mathrm{~b}$ & $0.14 \pm 0.02 \mathrm{a}$ & $0.76 \pm 0.03 \mathrm{bc}$ & $0.10 \pm 0.01 \mathrm{~b}$ \\
\hline T3 & $0.95 \pm 0.03 \mathrm{a}$ & $26.08 \pm 1.50 \mathrm{a}$ & $2.31 \pm 0.02 \mathrm{a}$ & $0.13 \pm 0.05 \mathrm{a}$ & $0.93 \pm 0.22 \mathrm{ab}$ & $0.13 \pm 0.00 \mathrm{c}$ \\
\hline
\end{tabular}

Table 4. Effects of the mixture of rice husk ash and red soil with various proportions on growth parameters of cotton seedlings.

\begin{tabular}{|l|l|l|l|l|l|l|}
\hline Treatment & $\begin{array}{l}\text { Shoot fresh weight } \\
(\mathbf{g})\end{array}$ & $\begin{array}{l}\text { Shoot dry weight } \\
(\mathbf{g})\end{array}$ & $\begin{array}{l}\text { Root fresh weight } \\
(\mathbf{g})\end{array}$ & $\begin{array}{l}\text { Root dry weight } \\
(\mathbf{g})\end{array}$ & $\begin{array}{l}\text { Total fresh weight } \\
(\mathbf{g})\end{array}$ & $\begin{array}{l}\text { Total dry weight } \\
(\mathrm{g})\end{array}$ \\
\hline T0 & $2.47 \pm 0.17 \mathrm{c}$ & $0.67 \pm 0.03 \mathrm{~d}$ & $0.75 \pm 0.24 \mathrm{~b}$ & $0.09 \pm 0.02 \mathrm{~b}$ & $3.21 \pm 0.09$ & $0.76 \pm 0.02 \mathrm{~d}$ \\
\hline T1 & $5.28 \pm 0.52 \mathrm{a}$ & $1.51 \pm 0.18 \mathrm{a}$ & $1.67 \pm 0.14 \mathrm{a}$ & $0.18 \pm 0.02 \mathrm{a}$ & $6.95 \pm 0.52 \mathrm{a}$ & $1.69 \pm 0.18 \mathrm{a}$ \\
\hline T2 & $3.43 \pm 0.20 \mathrm{~b}$ & $0.90 \pm 0.09 \mathrm{~b}$ & $1.17 \pm 0.03 \mathrm{ab}$ & $0.13 \pm 0.00 \mathrm{ab}$ & $4.60 \pm 0.18 \mathrm{c}$ & $1.03 \pm 0.08 \mathrm{c}$ \\
\hline T3 & $4.06 \pm 0.36 \mathrm{~b}$ & $1.28 \pm 0.07 \mathrm{c}$ & $1.25 \pm 0.57 \mathrm{ab}$ & $0.16 \pm 0.06 \mathrm{a}$ & $5.31 \pm 0.34 \mathrm{~b}$ & $1.44 \pm 0.04 \mathrm{~b}$ \\
\hline
\end{tabular}

Table 5. Effects of the mixture of rice husk ash and red soil with various proportions on fresh (dry) weight of cotton seedlings.

\begin{tabular}{|l|l|l|l|l|l|l|}
\hline Treatment & Total length $(\mathbf{m m})$ & Surface area $\left(\mathbf{c m}^{2}\right)$ & Root volume $\left.\mathbf{( c m}^{3}\right)$ & $\begin{array}{l}\text { Average diameter } \\
(\mathbf{m m})\end{array}$ & Number of tips & $\begin{array}{l}\text { Root vigor } \\
\left(\boldsymbol{\mu g} \mathbf{g}^{-1} \mathbf{h}^{-1}\right)\end{array}$ \\
\hline T0 & $124.43 \pm 19.65 \mathrm{~b}$ & $23.64 \pm 4.75 \mathrm{~b}$ & $0.36 \pm 0.09 \mathrm{~b}$ & $0.60 \pm 0.05 \mathrm{ab}$ & $78.22 \pm 22.69 \mathrm{~b}$ & $16.68 \pm 0.61 \mathrm{a}$ \\
\hline T1 & $245.90 \pm 30.62 \mathrm{a}$ & $52.76 \pm 10.11 \mathrm{a}$ & $0.92 \pm 0.26 \mathrm{a}$ & $0.68 \pm 0.09 \mathrm{a}$ & $186.33 \pm 62.96 \mathrm{a}$ & $20.47 \pm 7.38 \mathrm{a}$ \\
\hline T2 & $143.92 \pm 26.03 \mathrm{~b}$ & $24.91 \pm 4.25 \mathrm{~b}$ & $0.34 \pm 0.06 \mathrm{~b}$ & $0.55 \pm 0.01 \mathrm{~b}$ & $76.44 \pm 33.48 \mathrm{~b}$ & $16.74 \pm 7.27 \mathrm{a}$ \\
\hline T3 & $223.15 \pm 37.69 \mathrm{a}$ & $39.77 \pm 9.28 \mathrm{a}$ & $0.57 \pm 0.19 \mathrm{~b}$ & $0.56 \pm 0.06 \mathrm{~b}$ & $167.89 \pm 53.63 \mathrm{a}$ & $19.16 \pm 3.34 \mathrm{a}$ \\
\hline
\end{tabular}

Table 6. Effects of the mixture of rice husk ash and red soil with various proportions on root architectures of cotton seedling.

gence rate and root to shoot ratio between the RHA application and the control (Table 4). Similarly, the RHA addition also increased shoot dry (fresh) weight, root dry (fresh) weight and total dry (fresh) weight, and T1 documented the maximums among various treatments with the shoot, root and total dry weight being greater by $1.3,1.0$ and 1.2 times than the control, respectively (Table 5). Root architectures were improved by the RHA application (Table 6). Total root length, root surface area and numbers of tips were greater in T1 and T2, and root volume was greater in $\mathrm{T} 1$ relative to $\mathrm{T} 0$. No difference was observed in these root parameters between $\mathrm{T} 2$ and T0 (Table 6). The above results mean only a higher RHA application rate $\geq 50 \%$ volume ratio can contribute to the occurrence and growth of roots. T1 was found to be the optimal treatment with the best root architecture properties.

Seedling physiological parameters. Sucrose and hexose concentrations in leaves were increased with the application of RHA, but no difference in the starch and total nonstructural carbohydrate concentrations (Fig. 1), which means the RHA application may improve the photosynthetic capacity of the cotton seedling leaf. Sucrose, starch and total nonstructural concentrations in roots were decreased with the application of RHA except T3, and T2 showed significant differences from T0 (Fig. 1a,c,d). Sucrose concentration in stems was decreased, but hexose concentration was increased by the RHA application (Fig. 1a,b). The application of RHA did not influence root vigor (Table 6). Total carbon concentration in the stem and root did not change with the application of RHA, but total nitrogen contents were decreased which led to enhanced carbon to nitrogen ratios 

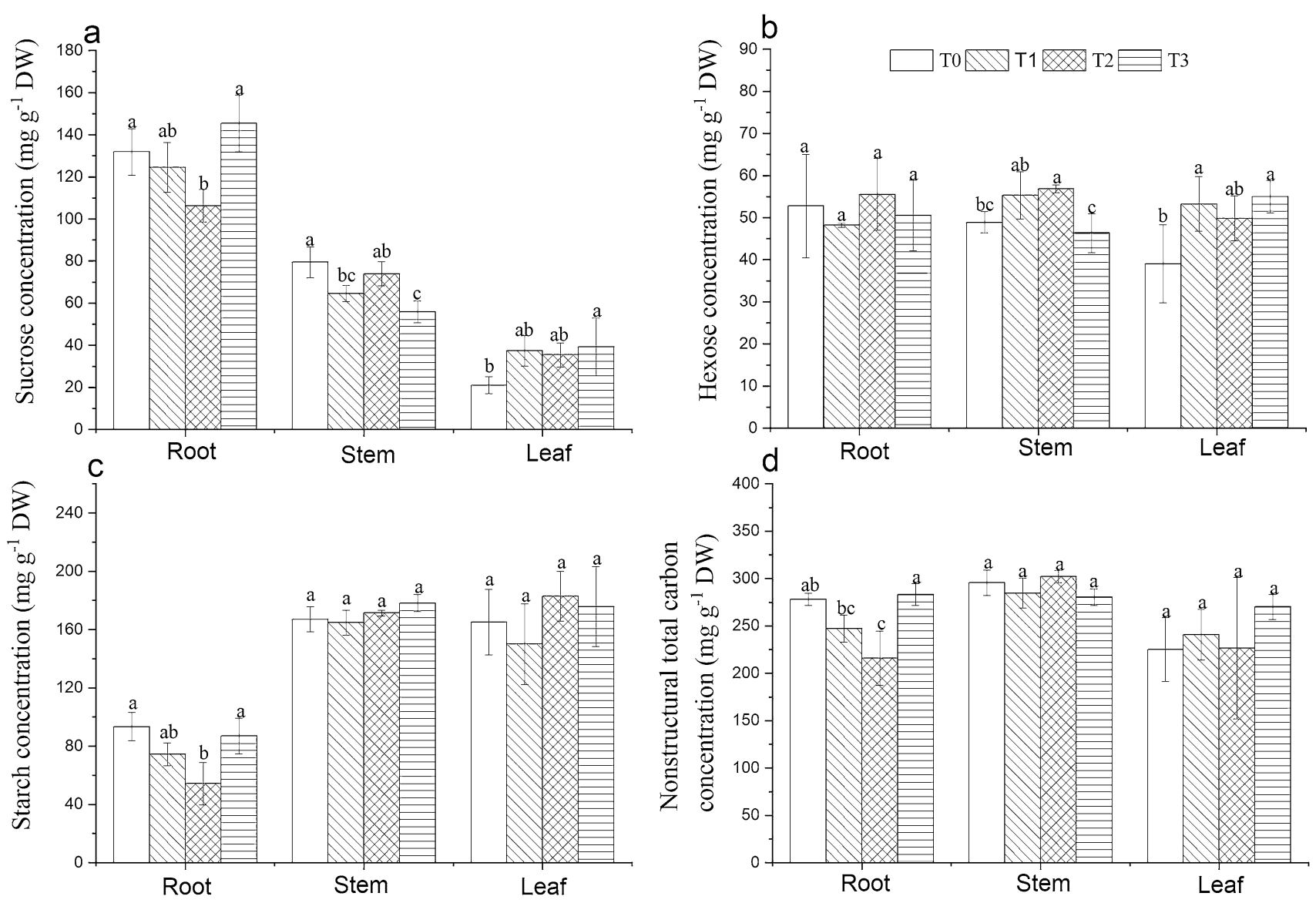

Figure 1. Effects of the mixtures of red soil and rice husk ash with various proportions on the sucrose (a), hexose (b), starch (c) and total nonstructural carbohydrate (d) concentrations in the root, stem and leaf of cotton seedlings. Histograms denote means $\pm \mathrm{SD}$, and diverse letters over which indicate significant difference at $P \leq 0.05$ level. T0, T1, T2, and T3 represent the mixture of red soil to RHA at volume ratios of 1:0, 1:1, 2:1, and $1: 2$, respectively.

in the stem and root (Table 7). The RHA application increased total carbon and total nitrogen accumulations summed across the whole plant with the maximums recorded in T1 (Table 7).

Comparison of a synthetic growing media containing RHA and a commercial growing media in facilitating cotton seedling growth. In experiment 1 , the mixture of red soil and RHA at a 1:1 volume ratio (T1) was convinced to be the optimal growing media for cotton seedlings in terms of its benefits on soil and seedling properties in combination with cost-efficiency. Further, we examined the effects of super absorbent polymers (SAP) at various application rates, and mepiquat chloride (MC) involved in different usage doses and application timings on cotton seedling growth on the T1 treatment basis. Two $\mathrm{g} \mathrm{L}^{-1} \mathrm{SAP}$ as potassium polyacrylamide and $50 \mathrm{mg} \mathrm{L}^{-1} \mathrm{MC}$ foliar painting at the one-true-leaf stage were determined as the most suitable treatment following a series of gradient tests, respectively (data not shown). In experiment 2, a synthetic growing media involved in T1 combined with SAP was employed to examine its application perspective in nursing cotton seedling with a widely used commercial growing media (CM) as the control. A total of four treatments were included in experiment 2. Except T0, the other three treatments were subjected to the same MC foliar painting of $50 \mathrm{mg} \mathrm{L}^{-1}$ at the one-true-leaf stage. The usage of $\mathrm{MC}$ was aimed to oppress tall-footed seedlings and strengthen root architecture. Three treatments with MC application had greater stem diameter, root to shoot ratio, seedling index, root fresh weight, root dry weight and root vigor than that without MC application (Tables 8, 9, 10). Compared to $\mathrm{CM}+\mathrm{MC}(\mathrm{T} 7), \mathrm{T} 1+\mathrm{SAP}+\mathrm{MC}$ (T6) recorded greater shoot fresh weight and total fresh weight, but smaller plant height, root fresh weight and root dry weight (Tables 8,9 ). In the case of root architectures, total root length and number of root tips were greater, but the average diameter was smaller in $\mathrm{CM}+\mathrm{MC}$ than in $\mathrm{T} 1+\mathrm{SAP}+\mathrm{MC}$. The other growth parameters and root characteristics did not differ from each other (Table 10). Notably, both treatments had much better performance than the pure soil treatment (T1) in improving seedling properties. Taken together, the growing media (RHA mixed with red soil in a volume ratio of 1:1 plus $2 \mathrm{~g} \mathrm{~L}^{-1}$ SAP) is comparable to the commercial media in nursing cotton seedlings. 


\begin{tabular}{|c|c|c|c|c|c|}
\hline Treatment & $\begin{array}{l}\text { Total carbon } \\
\text { concentration }\left(\mathrm{g} \mathrm{kg}^{-1}\right)\end{array}$ & $\begin{array}{l}\text { Total carbon per plant } \\
(\mathrm{mg})\end{array}$ & $\begin{array}{l}\text { Total nitrogen } \\
\text { content (\%) }\end{array}$ & $\begin{array}{l}\text { Total nitrogen per } \\
\text { plant }(\mathrm{mg})\end{array}$ & $\begin{array}{l}\text { Carbon to nitrogen } \\
\text { ratio }\end{array}$ \\
\hline \multicolumn{6}{|l|}{ Root } \\
\hline T0 & $437.72 \pm 5.67 \mathrm{a}$ & $39.34 \pm 8.45 b$ & $1.44 \pm 0.16 \mathrm{a}$ & $1.32 \pm 0.43 \mathrm{a}$ & $30.61 \pm 3.86 \mathrm{c}$ \\
\hline $\mathrm{T} 1$ & $400.21 \pm 19.14 \mathrm{a}$ & $71.45 \pm 8.77 \mathrm{a}$ & $1.01 \pm 0.03 \mathrm{~b}$ & $1.80 \pm 0.21 \mathrm{a}$ & $39.60 \pm 0.62 b$ \\
\hline $\mathrm{T} 2$ & $406.78 \pm 32.91 \mathrm{a}$ & $51.90 \pm 2.75 \mathrm{~b}$ & $1.06 \pm 0.07 \mathrm{~b}$ & $1.36 \pm 0.09 \mathrm{a}$ & $38.26 \pm 2.60 \mathrm{~b}$ \\
\hline T3 & $419.16 \pm 25.15 \mathrm{a}$ & $52.68 \pm 8.32 \mathrm{~b}$ & $0.90 \pm 0.13 b$ & $1.07 \pm 0.11 \mathrm{a}$ & $47.10 \pm 3.97 \mathrm{a}$ \\
\hline \multicolumn{6}{|l|}{ Stem } \\
\hline T0 & $464.77 \pm 1.76 \mathrm{a}$ & $167.82 \pm 6.92 \mathrm{~b}$ & $0.59 \pm 0.01 \mathrm{a}$ & $2.11 \pm 0.10 c$ & $79.46 \pm 0.86 c$ \\
\hline $\mathrm{T} 1$ & $462.85 \pm 1.92 \mathrm{a}$ & $419.22 \pm 59.98 \mathrm{a}$ & $0.44 \pm 0.03 c$ & $3.96 \pm 0.36 a$ & $105.61 \pm 6.54 \mathrm{a}$ \\
\hline $\mathrm{T} 2$ & $453.92 \pm 17.75 \mathrm{a}$ & $218.09 \pm 17.07 \mathrm{~b}$ & $0.49 \pm 0.01 \mathrm{~b}$ & $2.34 \pm 0.08 \mathrm{c}$ & $93.31 \pm 4.67 \mathrm{~b}$ \\
\hline $\mathrm{T} 3$ & $459.36 \pm 4.17 \mathrm{a}$ & $383.74 \pm 10.58 \mathrm{a}$ & $0.41 \pm 0.01 \mathrm{~d}$ & $3.39 \pm 0.10 \mathrm{~b}$ & $113.30 \pm 3.27 \mathrm{a}$ \\
\hline \multicolumn{6}{|l|}{ Leaf } \\
\hline T0 & $470.35 \pm 4.49 \mathrm{a}$ & $147.33 \pm 7.58 \mathrm{c}$ & $1.61 \pm 0.21 \mathrm{a}$ & $5.01 \pm 0.34 \mathrm{~b}$ & $29.56 \pm 3.37 \mathrm{a}$ \\
\hline $\mathrm{T} 1$ & $473.77 \pm 0.48 \mathrm{a}$ & $285.83 \pm 34.12 \mathrm{a}$ & $1.42 \pm 0.12 \mathrm{a}$ & $8.52 \pm 0.42 a$ & $33.51 \pm 2.75 \mathrm{a}$ \\
\hline $\mathrm{T} 2$ & $469.58 \pm 11.41 \mathrm{a}$ & $198.64 \pm 36.28 \mathrm{bc}$ & $1.31 \pm 0.18 \mathrm{a}$ & $5.45 \pm 0.44 \mathrm{~b}$ & $36.40 \pm 5.14 \mathrm{a}$ \\
\hline $\mathrm{T} 3$ & $473.02 \pm 11.57 \mathrm{a}$ & $209.44 \pm 23.07 \mathrm{~b}$ & $1.31 \pm 0.17 \mathrm{a}$ & $5.79 \pm 1.04 \mathrm{~b}$ & $36.59 \pm 4.44 \mathrm{a}$ \\
\hline \multicolumn{6}{|l|}{ Sum } \\
\hline T0 & - & $354.49 \pm 7.57 \mathrm{~d}$ & - & $8.44 \pm 0.68 \mathrm{c}$ & $42.20 \pm 3.90 \mathrm{c}$ \\
\hline $\mathrm{T} 1$ & - & $776.50 \pm 87.63 \mathrm{a}$ & - & $14.28 \pm 0.83 \mathrm{a}$ & $54.29 \pm 3.58 \mathrm{~b}$ \\
\hline $\mathrm{T} 2$ & - & $468.63 \pm 53.80 \mathrm{c}$ & - & $9.14 \pm 0.41 \mathrm{bc}$ & $51.21 \pm 4.61 \mathrm{~b}$ \\
\hline T3 & - & $645.85 \pm 28.05 \mathrm{~b}$ & - & $10.25 \pm 1.06 \mathrm{~b}$ & $63.36 \pm 5.64 \mathrm{a}$ \\
\hline
\end{tabular}

Table 7. Effects of the mixture of rice husk ash and red soil with various proportions on the carbon and nitrogen status in different parts of cotton seedlings.

\begin{tabular}{|l|c|l|l|l|l|}
\hline Treatment & Plant height $\mathbf{( c m})$ & Stem diameter $(\mathbf{m m})$ & Root to shoot ratio & Seedling index & G value $\left(\mathbf{m g ~ d a y}^{-1}\right)$ \\
\hline T0 & $9.89 \pm 0.49 \mathrm{~b}$ & $2.05 \pm 0.03 \mathrm{c}$ & $0.17 \pm 0.02 \mathrm{~b}$ & $0.99 \pm 0.06 \mathrm{c}$ & $0.07 \pm 0.01 \mathrm{~b}$ \\
\hline T1 + MC & $8.06 \pm 0.40 \mathrm{c}$ & $2.25 \pm 0.08 \mathrm{~b}$ & $0.27 \pm 0.02 \mathrm{a}$ & $1.26 \pm 0.13 \mathrm{~b}$ & $0.06 \pm 0.00 \mathrm{~b}$ \\
\hline T1 + SAP + MC & $9.72 \pm 0.27 \mathrm{~b}$ & $2.76 \pm 0.04 \mathrm{a}$ & $0.23 \pm 0.04 \mathrm{a}$ & $2.33 \pm 0.12 \mathrm{a}$ & $0.12 \pm 0.01 \mathrm{a}$ \\
\hline CM + MC & $10.91 \pm 0.22 \mathrm{a}$ & $2.77 \pm 0.04 \mathrm{a}$ & $0.23 \pm 0.01 \mathrm{a}$ & $2.46 \pm 0.05 \mathrm{a}$ & $0.13 \pm 0.00 \mathrm{a}$ \\
\hline
\end{tabular}

Table 8. Effects of different growing media combined with MC application on growth parameters of cotton seedlings. $C M$ commercial media, SAP super absorbent polymer, $M C$ mepiquat chloride foliar painting at the one-true-leaf stage.

\begin{tabular}{|l|l|l|l|l|l|l|}
\hline Treatment & $\begin{array}{l}\text { Shoot fresh } \\
\text { weight }(\mathbf{g})\end{array}$ & $\begin{array}{l}\text { Shoot dry weight } \\
(\mathbf{g})\end{array}$ & $\begin{array}{l}\text { Root fresh weight } \\
(\mathbf{g})\end{array}$ & $\begin{array}{l}\text { Root dry weight } \\
(\mathbf{g})\end{array}$ & $\begin{array}{l}\text { Total fresh weight } \\
(\mathbf{g})\end{array}$ & $\begin{array}{l}\text { Total dry weight } \\
(\mathbf{g})\end{array}$ \\
\hline T0 & $3.69 \pm 0.42 \mathrm{c}$ & $0.74 \pm 0.11 \mathrm{~b}$ & $1.31 \pm 0.05 \mathrm{~d}$ & $0.13 \pm 0.01 \mathrm{~d}$ & $5.00 \pm 0.39 \mathrm{c}$ & $0.87 \pm 0.11 \mathrm{~b}$ \\
\hline T1 + MC & $3.08 \pm 0.11 \mathrm{~d}$ & $0.61 \pm 0.04 \mathrm{~b}$ & $1.97 \pm 0.22 \mathrm{c}$ & $0.16 \pm 0.01 \mathrm{c}$ & $5.04 \pm 0.18 \mathrm{c}$ & $0.77 \pm 0.04 \mathrm{~b}$ \\
\hline T1 + SAP + MC & $7.83 \pm 0.18 \mathrm{a}$ & $1.26 \pm 0.19 \mathrm{a}$ & $3.68 \pm 0.04 \mathrm{~b}$ & $0.28 \pm 0.01 \mathrm{~b}$ & $11.50 \pm 0.19 \mathrm{a}$ & $1.53 \pm 0.19 \mathrm{a}$ \\
\hline CM + MC & $6.12 \pm 0.19 \mathrm{~b}$ & $1.37 \pm 0.01 \mathrm{a}$ & $4.14 \pm 0.14 \mathrm{a}$ & $0.32 \pm 0.01 \mathrm{a}$ & $10.26 \pm 0.10 \mathrm{~b}$ & $1.69 \pm 0.00 \mathrm{a}$ \\
\hline
\end{tabular}

Table 9. Effects of different growing media combined with MC application on the fresh (dry) weight of cotton seedlings. CM commercial media, SAP super absorbent polymer, $M C$ mepiquat chloride foliar painting at the one-true-leaf stage.

\begin{tabular}{|l|l|l|l|l|l|l|}
\hline Treatment & $\begin{array}{l}\text { Total length } \\
(\mathbf{m m})\end{array}$ & $\begin{array}{l}\text { Surface area } \\
\left(\mathbf{c m}^{2}\right)\end{array}$ & $\begin{array}{l}\text { Root volume } \\
\left(\mathbf{c m}^{3}\right)\end{array}$ & $\begin{array}{l}\text { Average diameter } \\
(\mathbf{m m})\end{array}$ & $\begin{array}{l}\text { Number of root } \\
\mathbf{t i p s}\end{array}$ & $\begin{array}{l}\text { Root vigor } \\
\left(\boldsymbol{\mu g} \mathbf{g}^{-1} \mathbf{h}^{-1}\right)\end{array}$ \\
\hline T0 & $94.30 \pm 1.47 \mathrm{c}$ & $21.23 \pm 1.13 \mathrm{~b}$ & $0.37 \pm 0.01 \mathrm{~b}$ & $0.72 \pm 0.04 \mathrm{~b}$ & $91.11 \pm 5.67 \mathrm{c}$ & $73.61 \pm 3.09 \mathrm{c}$ \\
\hline T1+MC & $110.21 \pm 7.08 \mathrm{c}$ & $25.23 \pm 1.61 \mathrm{~b}$ & $0.47 \pm 0.03 \mathrm{~b}$ & $0.74 \pm 0.01 \mathrm{~b}$ & $95.00 \pm 8.41 \mathrm{c}$ & $84.23 \pm 2.70 \mathrm{~b}$ \\
\hline T1+SAP + MC & $166.36 \pm 14.95 \mathrm{~b}$ & $54.08 \pm 6.44 \mathrm{a}$ & $1.47 \pm 0.39 \mathrm{a}$ & $1.08 \pm 0.16 \mathrm{a}$ & $162.67 \pm 17.78 \mathrm{~b}$ & $114.79 \pm 4.53 \mathrm{a}$ \\
\hline $\mathrm{CM}+\mathrm{MC}$ & $194.40 \pm 12.85 \mathrm{a}$ & $51.31 \pm 3.59 \mathrm{a}$ & $1.13 \pm 0.27 \mathrm{a}$ & $0.87 \pm 0.14 \mathrm{~b}$ & $287.56 \pm 8.59 \mathrm{a}$ & $119.12 \pm 6.76 \mathrm{a}$ \\
\hline
\end{tabular}

Table 10. Effects of different growing media combined with MC application on the root architectures of cotton seedlings. CM commercial media, SAP super absorbent polymer, $M C$ mepiquat chloride foliar painting at the one-true-leaf stage. 


\section{Discussion}

Rice husk is produced in large quantity during the process of rice milling which can be burned to generate steam or electricity, and the resultant rice husk ash (RHA) is left. It will be a pollutant on inappropriate disposal. RHA is characterized by lightweight, high SSA, porosity and durability, and good chemical stability ${ }^{8,29}$. Thus, it presents an enormous application value as a bioadsorbent for the removal of heavy metals and other toxic organic compounds from contaminated soil and water, but its utilization as a growing media is less investigated. In the present study, RHA incorporation into red soil at different rates was found to improve soil properties and cotton seedling growth parameters. RHA has a wide range of attributes similar to biochar like $\mathrm{RHB}^{10,16}$, but draw much less attention to its application in the agriculture industry than biochar, and thus relevant reports are limited. The following discussion is presented largely combined with biochar related studies.

Soil bulk density was decreased by the application rate of RHA equal to or above $50 \%$ by volume (Table 2 ). RHA incorporation rate at $33 \%$ by volume (T2) did not significantly modify the soil properties such as bulk density and total porosity (Table 2). The decreased bulk density in the mixed red soil should be derived from the small bulk density of RHA itself, a similar result as reported by Chang et al. ${ }^{22}$ who found decreased bulk density in sandy soil by pinewood biochar. Scanning electron micrograph (SEM) and transmission electron micrograph (TEM) analyses of the RHA microstructure indicated two kinds of pores present in RHA with one being microsized pores (around $10 \mu \mathrm{m}$ ) formed by interlacing of the fiber sheet and the other one being nanosized pores $(<50 \mathrm{~nm})$ formed by nano $\mathrm{SiO}_{2}$ particles ${ }^{30}$. The nanopores and nano $\mathrm{SiO}_{2}$ particles are the crucial contributors to specific surface area and high activity of RHA. Similarly, Singh et al. also observed various macro- and micro-pores on the surface of RHA ${ }^{14}$. The existence of pores with a diameter range of 0.1 to $10 \mu \mathrm{m}$ in a crop straw biochar can help improve the WHC of soil ${ }^{31}$. The biochar application rate was positively correlated with the WHC of biochar-amended soil when the former was below $20 \%$, which means the presence of an optimal value of biochar application rate for maximizing the $\mathrm{WHC}^{22}$. The present study indicated a positive correlation between WHC and RHA application rate (Table 2).

The $\mathrm{pH}$ value was increased with increasing RHA incorporation rate (Table 3). RHA was moderately alkaline with a $\mathrm{pH}$ of 7.89 (Table 1) and featured by high neutralizing power, which is suitable for neutralization of acid soils ${ }^{17}$. The red soil in the present study is originally acidic and turned less acidic after the RHA incorporation (Table 3), as observed by Masulili et al. ${ }^{12}$. The higher $\mathrm{pH}$ of RHA may be attributed to the formation of carbonates during the combustion process ${ }^{12}$. Soil $\mathrm{pH}$ can affect the microbial abundance, diversity, and activity ${ }^{32}$. For example, the moderate alkalinity of RHA benefits soil bacterial communities accounting for rapid mineralization of organic matter and its microbial recruitment ${ }^{33}$. Typical acid red soil is a shortage of available $\mathrm{K}, \mathrm{P}, \mathrm{Ca}$ and $\mathrm{Mg}$ due to leaching under the subtropical monsoon climate with high precipitation and temperature ${ }^{2}$. By contrast, RHA is rich in available $\mathrm{K}$ and $\mathrm{P}$ (Table 1 ). Thus, RHA can directly enhance the nutrient availability of red soil as a primary source of nutrients. On the other hand, RHA can indirectly improve nutrient supply to plants owing to its high active surface, and the existence of couples of reactive functional groups affecting adsorption ${ }^{17,34}$. Fourier transform infrared spectroscopy (FTIR) analysis of RHA indicated it carries functional groups like hydroxyl $(-\mathrm{OH})$, silanols $(\mathrm{Si}-\mathrm{OH})$ and siloxanes $(\mathrm{Si}-\mathrm{O}-\mathrm{Si}-\mathrm{OH})$ groups, but carboxylic radicals $(-\mathrm{COOH})$ was not detected ${ }^{10}$. RHA is expected to increase soil CEC because of its good porosity and large and predominately negative charged surface functional groups, and the adsorption of organic matter on RHA surfaces. More cationic nutrients can be absorbed by a soil with a higher CEC than that with a lower CEC, so nutrients are retained other than leached and thus more available for plant uptake ${ }^{35}$.

RHA application improved the cotton seedling growth (Tables 4,5 ), which is partly attributed to enhanced nutrient availability and $\mathrm{pH}$ (Table 3 ). Tian et al. reported that biochar derived from green waste combined with peat at a ratio of 1:1 by volume enhanced total biomass and leaf surface area of Calathea rotundifolia relative to peat substrate alone, which was associated with improved substrate attributes and increased nutrient availability on biochar addition ${ }^{36}$. Lettuce biomass was increased by $184-270 \%$ after the replacement of $10 \%$ peat (by volume) by sewage sludge biochar, which was attributed to enhanced N, P and K contents and microbial activities in growing media ${ }^{37}$. Increased biomass accumulation may be the result of increased inorganic nutrient uptake and photosynthetic production together. The former can be owing to enhanced nutrient availability due to RHA incorporation. The latter could be explained by the carbohydrate change in leaves occasioned by RHA addition. The hexose and sucrose concentrations in leaves were increased, but starch concentration was not affected by the RHA addition (Fig. 1a-c), suggesting greater photosynthetic productivity and carbon export availability in leaves. The root architecture of cotton seedlings was improved by RHA application treatments, among which T1 recorded the best performance (Table 4). Similar observations were reported in Muscadine grape (Vitis rotundifolia L.) and sugarcane $\mathrm{e}^{22,38}$. Pinewood biochar addition to pure sandy soil improved soil physical characteristics and facilitated the root growth and development of potted Muscadine grape (Vitis rotundifolia L. $)^{22}$. Cassava stem derived biochar application enhanced the soil fertility and $\mathrm{pH}$, and improved the root properties of sugarcane seedlings in a potted experiment ${ }^{38}$. The increased root growth may be ascribable to improved soil physical properties helping the roots more easily access to air and water and less acidic $\mathrm{pH}$ which may be beneficial to microbial activities ${ }^{33}$. On the other hand, the improved root growth may be associated with the enhanced soluble sugars concentration in the leaf which is typically considered as an indicator of active photosynthesis under normal growth conditions ${ }^{39}$. For instance, the root growth of Arabidopsis seedlings at the early stage was prompted by the photosynthetic sucrose as a long-distance signal molecule ${ }^{40}$. Exogenous application of sugar can increase free auxin levels and basipetal auxin transport in Arabidopsis seedlings and promote the elongation of the hypocotyl and roots ${ }^{41}$. Sucrose application to the shoot of Arabidopsis alone triggered the emergence of lateral root primordia ${ }^{42}$. Druege et al. found that increased rooting of chrysanthemum cuttings was associated with higher sucrose: starch ratios in leaves ${ }^{43}$. The result accords well with the present study where increased 
sucrose concentration in combination with an invariable starch concentration in leaves due to RHA incorporation produced increased sucrose to starch ratios which were accompanied by enhanced root tips (Table 6, Fig. 1b,c).

$\mathrm{T} 1+\mathrm{SAP}+\mathrm{MC}$ and $\mathrm{CM}+\mathrm{MC}$ performed better than the two other treatments, and did not differ significantly from each other in a majority of parameters tested (Tables 8, 9, 10). Peat is a major composition included in commercial growing media pushing its price to a high level, which is a non-renewable source due to its very long regeneration time. A large amount of exploitation of peat will impose severe damage on the environment as it provides certain ecosystem services such as biodiversity, water regulation and $\mathrm{C}$ sinks ${ }^{17}$. RHA possesses many physico-chemical properties similar to peat, and its usage as an additive to red soil exhibited desirable effects on nursing seedlings comparable to commercial growing media. Thus, RHA will be a promising substitute for peat as growing media, which is also of great implication for the development of circular economy in the agriculture sector.

\section{Conclusions}

Red soil is characterized by low $\mathrm{pH}$ value, and deficient available $\mathrm{P}$ and $\mathrm{K}$, total $\mathrm{N}$, and organic matter. The addition of RHA counteracts the acidity of red soil and improves the nutrient availability to plants. Bulk density was decreased and water holding capacity and total porosity were increased in red soil with increasing application rate of RHA. The RHA incorporated soils favored the growth of cotton seedlings with improved shoot morphological traits and root architectures. The application rate at a volume ratio of 1:1 of RHA to red soil was found to be optimal for growing cotton seedlings in the present study. The mixture of RHA and red soil at a 1:1 volume ratio plus $2 \mathrm{~g} \mathrm{~L}^{-1}$ SAP exhibited a high nursing seedling efficiency comparable to a commercial growing media under the condition of foliar application of mepiquat chloride at the one-true-leaf stage. RHA is a desirable substance for ameliorating the red soil properties and can replace peat as growing media for nursing cotton seedlings.

\section{Data availability}

Raw data were generated at College of Agronomy Jiangxi Agricultural University. Derived data supporting the finding of this study are available from the corresponding author (FT) on request.

Received: 11 September 2021; Accepted: 7 January 2022

Published online: 01 February 2022

\section{References}

1. Liu, X. \& He, X. Progress and achievement in the research on red soil in Jiangxi. Acta. Agric. Jiangxi 3, 66-75 (1991).

2. Zhang, W., Xu, M., Wang, B. \& Wang, X. Soil organic carbon, total nitrogen and grain yields under long-term fertilizations in the upland red soil of southern China. Nutr. Cycl. Agroecosyst. 84, 59-69 (2009).

3. Zhang, H., Wang, B., Xu, M. \& Fan, T. Crop yield and soil responses to long-term fertilization on a red soil in southern China. Pedosphere 19, 199-207 (2009).

4. Wu, L., Yang, L., Tang, Y., Liu, B. \& Kang, X. Research on regional competitiveness of cotton industry in Jiangxi province. Cotton Sci. 41, 35-40 (2019).

5. Zhang, J., Jiang, M., Xie, P. \& Cao, S. Obstacle factors and increasing production methods for growing cotton in the red soil dryland. Cotton Sci. 35, 37-38 (2013).

6. He, X. et al. Suggestions on innovative development of rice seed industry in Jiangxi province. Acta Agric. Univ. Jiangxi 43, 479-487 (2021).

7. Nagrale, S. D., Hajare, H. \& Modak, P. R. Utilization of rice husk ash. Int. J. Eng. Res. Appl. 2, 1-5 (2012).

8. Zou, Y. \& Yang, T. Rice husk, rice husk ash and their applications. In Rice Bran and Rice Bran Oil. (eds Cheong, L. \& Xu, X.) 207-246 (Elsevier Inc., 2019).

9. Prasara-A, J. \& Gheewala, S. H. Sustainable utilization of rice husk ash from power plants: A review. J. Clean. Prod. https://doi. org/10.1016/j.jclepro.2016.11.042 (2016).

10. Severo, F. F. et al. Chemical and physical characterization of rice husk biochar and ashes and their iron absorption capacity. $S N$ Appl. Sci. 2, 1286 (2020).

11. Liu, X. et al. A review on recent advances in the comprehensive application of rice husk ash. Res. Chem. Intermed. https://doi.org/ 10.1007/s11164-015-2061-y (2015).

12. Masulili, A., Utomo, W. H. \& Syechfani, M. S. Rice husk biochar for rice based cropping system in acid soil 1 . The characteristics of rice husk biochar and its influence on the properties of acid sulfate soils and rice growth in west Kalimantan, Indonesia. J. Agric. Sci. 2, 39-47 (2010).

13. Xu, W. T., Lo, T. Y. \& Memon, S. A. Microstructure and reactivity of rice husk ash. Constr. Build. Mater. 29, 541-547 (2012).

14. Singh, R. et al. Impact of rice-husk ash on the soil biophysical and agronomic parameters of wheat crop under a dry tropical ecosystem. Ecol. Indic. 105, 505-515 (2019).

15. Kiran, B. R. \& Prasad, M. N. V. Biochar and rice husk ash assisted phytoremediation potentials of Ricinus communis L. for leadspiked soils. Ecotoxicol. Environ. Saf. 183, 109574 (2019).

16. Leksungnoen, P. et al. Biochar and ash derived from silicon-rich rice husk decrease inorganic arsenic species in rice grain. Sci. Total Environ. 684, 360-370 (2019).

17. Jindo, K. et al. Role of biochar in promoting circular economy in the agriculture sector. Part 2: A review of the biochar roles in growing media, composting and as soil amendment. Chem. Biol. Technol. Agric. 7, 16 (2020).

18. Peng, D., Gu, M., Zhao, Y., Yu, F. \& Choi, H. S. Effects of biochar mixes with peat moss based substrates on growth and development of horticultural crops. Hortic. Sci. Technol. 36, 501-512 (2018).

19. Banitalebi, G., Mosaddeghi, M. R. \& Shariatmadari, H. Feasibility of agricultural residues and their biochars for plant growing media: Physical and hydraulic properties. Wast. Manag. 87, 577-589 (2019).

20. Kaudal, B. B., Chen, D., Madhavan, D. B., Downie, A. \& Weatherley, A. Pyrolysis of urban waste streams: Their potential use as horticultural media. J. Anal. Appl. Pyrolysis. 112, 105-112 (2015).

21. Kern, J. et al. Synergistic use of peat and charred material in growing media-An option to reduce the pressure on peatlands?. J. Environ. Eng. Landsc. Manag. 25, 160-174 (2017).

22. Chang, Y. et al. Biochar improves soil physical characteristics and strengthens root architecture in Muscadine grape (Vitis rotundifolia L.). Chem. Biol. Technol. Agric. 8, 7 (2021).

23. Liu, H. Comparative analysis of soil properties in different vegetation of Xiaoliang, Maoming. J. Zhanjiang Norm. Coll. 31, 123-128 (2020). 
24. Lu, R. Analysis of soil nutrients. In Analysis Methods for Soil Agrochemistry (ed. Lu, R.) 164-194 (China Agricultural Science and Technology Press, 1999).

25. He, Y., Ji, Y., Zhang, Y., Wu, Z. \& Liu, M. Effects of different plant growth regulators on eggplant growth of plug seedling. Chin. Agric. Sci. Bull. 33, 46-53 (2017).

26. Luo, H. et al. Genotypic differences in sucrose metabolism with cotton bolls in relation to lint percentage. Field Crop Res. 236, 33-41 (2019).

27. Chen, G. et al. Effects of late planting on fiber quality and within-boll yield components as mediated by sucrose metabolism in cotton bolls. Arch. Agron. Soil Sci. 66, 1319-1333 (2020).

28. Chen, C. \& Li, H. Measurement of root vigor. In Principles and Techniques of Plant Physiological Biochemical Experiment (ed. Li, H.) 119-120 (Higher Education Press, 2000).

29. Della, V., Kühn, I. \& Hotza, D. Rice husk ash as an alternate source for active silica production. Mater. Lett. 57, 818-821 (2002).

30. Ouyang, D. \& Chen, K. SEM/TEM study on the microstructure of rice husk ash and nano- $\mathrm{SiO}_{2}$ in it. J. Chin. Electron. Microsc. Soc. 22, 390-394 (2003).

31. Liu, C. et al. Biochar increased water holding capacity but accelerated organic carbon leaching from a sloping farmland soil in China. Environ. Sci. Pollut. Res. Int. 23, 995-1006 (2016).

32. Rousk, J. et al. Soil bacterial and fungal communities across a pH gradient in an arable soil. ISME J. 4, 1340-1351 (2020).

33. Nardi, S., Morari, F., Berti, A., Tosoni, M. \& Giardini, L. Soil organic matter properties after 40 years of different use of organic and mineral fertilizers. Eur. J. Agron. 21, 357-367 (2004).

34. Agegnehu, G., Srivastava, A. K. \& Bird, M. I. The role of biochar and biochar-compost in improving soil quality and crop performance: A review. Appl. Soil. Ecol. 119, 156-170 (2017).

35. Purakayastha, T. J. et al. A review on biochar modulated soil condition improvements and nutrient dynamics concerning crop yields: Pathways to climate change mitigation and global food security. Chemosphere 227, 345-365 (2019).

36. Tian, Y. et al. Biochar made from green waste as peat substitute in growth media for Calathea rotundifola cv. Fasciata. Sci. Hortic. 143, 15-18 (2012).

37. Méndez, A., Cárdenas-Aguiar, E., Paz-Ferreiro, J., Plaza, C. \& Gascó, G. The effect of sewage sludge biochar on peat-based growing media. Biol. Agric. Hortic. 33, 40-51 (2017).

38. Yang, L., Liao, F., Huang, M., Yang, L. \& Li, Y. Biochar improves sugarcane seedling root and soil properties under a pot experiment. Sugar Tech. 17, 36-40 (2015).

39. Reddy, A. R., Reddy, K. R., Padjung, R. \& Hodge, H. F. Nitrogen nutrition and photosynthesis in leaves of Pima cotton. J. Plant Nutr. 19, 755-770 (1996).

40. Kircher, S. \& Schopfer, P. Photosynthetic sucrose acts as cotyledon-derived long-distance signal to control root growth during early seedling development in Arabidopsis. Proc. Natl. Acad. Sci. USA 109, 11217 (2012).

41. Lilley, J. L. S., Gee, C. W., Sairanen, I., Ljung, K. \& Nemhauser, J. L. An endogenous carbon-sensing pathway triggers increased auxin flux and hypocotyl elongation. Plant Physiol. 160, 2261-2270 (2012).

42. MacGregor, D. R., Deak, K. I., Ingram, P. A. \& Malamy, J. E. Root system architecture in Arabidopsis grown in culture is regulated by sucrose uptake in the aerial tissues. Plant Cell 20, 2643-2660 (2008).

43. Druege, U., Zerche, S., Kadner, R. \& Ernst, M. Relation between nitrogen status, carbohydrate distribution and subsequent rooting of chrysanthemum cuttings as affected by pre-harvest nitrogen supply and cold-storage. Ann. Bot. 85, 687-701 (2000).

\section{Acknowledgements}

This work was supported by the National Natural Science Foundation of China (Grant no. 31960385, 31560364).

\section{Author contributions}

M.Y. conducted the experiment, collected and analyzed the data. X.L. and Q.L. measured the water holding capacity. F.T. designed and supervised the experiment, analyzed the data, wrote the original draft, and revised the manuscript. All authors have read and approved of the final manuscript.

\section{Competing interests}

The authors declare no competing interests.

\section{Additional information}

Correspondence and requests for materials should be addressed to F.T.

Reprints and permissions information is available at www.nature.com/reprints.

Publisher's note Springer Nature remains neutral with regard to jurisdictional claims in published maps and institutional affiliations.

Open Access This article is licensed under a Creative Commons Attribution 4.0 International License, which permits use, sharing, adaptation, distribution and reproduction in any medium or format, as long as you give appropriate credit to the original author(s) and the source, provide a link to the Creative Commons licence, and indicate if changes were made. The images or other third party material in this article are included in the article's Creative Commons licence, unless indicated otherwise in a credit line to the material. If material is not included in the article's Creative Commons licence and your intended use is not permitted by statutory regulation or exceeds the permitted use, you will need to obtain permission directly from the copyright holder. To view a copy of this licence, visit http://creativecommons.org/licenses/by/4.0/.

(c) The Author(s) 2022 